\title{
10 health stories that mattered: Mar. 31-Apr. 4
}

- The expiry of the decade-old, \$41billion health accord between the federal government and the provinces and territories on Mar. 31 was lamented by many parties across the country. The Council of Canadians and the Canadian Health Coalition held a National Day of Action to "protect and strengthen public health care." Roy Romanow, author of the 2002 report Building on Values: The Future of Health Care in Canada, called it a sad day for Canada, telling the Toronto Star that "without leadership from Ottawa and with reduced money, we are going to see a further slowdown of reforms, more regional disparities and a push for more private health care."

- There are no negative health effects from exposure to radiofrequency energy below the limits in Canada's existing safety code, according to a review of evidence conducted by The Royal Society of Canada Expert Panel. "The Panel recommends that Health Canada should continue to monitor the literature for emerging evidence and that it aggressively pursue scientific research aimed at clarifying the radiofrequency energycancer issue and at further investigating the question of electromagnetic hypersensitivity, in particular," states the report.

- Providing medical care to wealthy international patients to generate revenue is the purpose of a pilot project at Sunnybrook Hospital in Toronto, Ontario, reports The Globe and Mail. The hospital plans to treat 10 international patients during the pilot. Critics of "inbound medical tourism," including Canadian Doc- tors for Medicare, say it could draw resources away from Canada's public health care system.

- Only $62.4 \%$ of hospitals in Canada report being adequately cleaned, and only $65.8 \%$ report that their cleaning staff are adequately trained, according to a survey of 119 hospitals. A reduction in antibiotic-resistant organisms could be achieved through additional training for environmental services workers and a more collaborative working relationship with infection prevention and control staff, the report concludes.

- The Choosing Wisely Canada campaigned launched Apr. 2, with nine national medical societies releasing lists of 40 tests, treatments and procedures that patients often don't need. The goal of the campaign is to promote effective medical care while avoiding unnecessary tests and procedures.

- Doctors should not accept gifts from pharmaceutical companies, promote products to colleagues or lend their names to ghostwritten studies, proposes draft guidelines for a new ethics policy by the College of Physicians and Surgeons of Ontario, reports the National Post. The proposed policy would still permit physicians to accept free lunches from drug reps, free drug samples, money for educational events and fees for speaking or consulting.

- Only 24 of 152 Health Canada drug reviews from last year are being considered for public release, reports The Toronto Star. Critics denounced the limited release, sug- gesting it indicates Health Canada is more concerned with commercial confidentiality than patient safety. In October, Health Minister Rona Ambrose told the Star that steps were being taken to "begin publishing drug reviews transparently to ensure Canadians and medical professionals have the information they need and want."

- Health Canada announced that it does not endorse the use of marijuana and noted that it is not an approved drug or medicine and has not gone through "the necessary rigorous scientific trials for efficacy or safety." However, the government believes that, because the courts have ruled that access to medical marijuana is permitted, it must control how the drug is produced and acquired.

- A few cases of measles in the state of Washington have been linked to the outbreak in British Columbia. There have been more than 300 cases of measles in BC's Fraser Valley. Overall, though, the spread of the virus outside of the region has been limited, according to Fraser Health.

- Questionable billing in Alberta worth $\$ 1.4$ million is being investigated by a special government unit set up to sniff out fraud in the medical system. The province's fee-for-service system has come under criticism for lack of adequate controls, reports The Calgary Herald. The special unit has laid charges against people for breach of trust, fraud, extra billing and trafficking of prescription medicine. Roger Collier, CMAJ

CMAJ 2014. DOI:10.1503/cmaj.109-4777 